\title{
7 \\ Deliberation: Manning Clark and the History Wars
}

If Manning Clark had not existed, it would have been necessary to invent him —or so he convinced us all. He cast a role model for himself in his national drama, as 'an Australian voice ... in the great debate on what it has all been for, telling the story of who Australians were and what they might be'. So Clark invented himself in his own image.

Marian Quartly (1994) ${ }^{1}$

Manning Clark wrote Australia's future as much he did its past.

Donald Wright $(2015)^{2}$

Manning Clark increasingly became the bête noire of Australian conservatives as he embraced the triple role of nationalist historian, pro-ALP activist and History Warrior. Yet he did not start out as a Labor partisan and it tends to be forgotten that Clark was sceptical of the ALP in the 1950s. There is also his association with Quadrant in its earlier days - ironically in view of the later attacks - when he was recruited to the journal's inaugural editorial board in 1955 as a voice of a progressive

1 Marian Quartly, 'Reinventing Manning Clark', Meanjin, vol. 53, no. 1, 1994, pp. 175-78, specifically p. 175. The quotation within the quotation comes from Manning Clark's History of Australia, abridged by Michael Cathcart, Melbourne: Melbourne University Press (hereafter MUP), 1993, p. 550. Quartly is Emerita Professor of History at Monash University.

2 Donald Wright, Donald Creighton: A Life in History, Toronto, University of Toronto Press, 2015, p. 321 . 
Australian conservatism. ${ }^{3}$ Clark's position shifted and from at least the mid-1970s he increasingly became a Labor icon. With the aura and gravitas of an Old Testament prophet, he became, in the popular imagination, 'the wise old man with a unique insight into the state of his country's soul'. ${ }^{4}$ Such was his value that the ALP machine gave him encouragement to provide 'an ever-deepening statement of the grand themes about our nature and the purpose of the continent' on its behalf. ${ }^{5}$

The turning point in Clark's relationship with the ALP stemmed from his admiration for Gough Whitlam (1916-2014). His public support of Labor became more strident after The Dismissal of the Whitlam Government in 1975. As well as asserting that 'History will be kinder to Labor than the people', he characterised the 23 years of Liberal-Country Party rule as 'the years of unleavened bread', denounced The Dismissal of the Whitlam Labor government ('Are we a nation of bastards?') and made ill-considered public statements that appeared to condone violent revolution. ${ }^{6} \mathrm{He}$ irked conservatives to the extent that members of the Fraser administration criticised the ABC's appointment of Clark to deliver the 1976 Boyer Lectures and unprecedented measures were taken to vet them. ${ }^{7}$ The final straw came with Clark's repeated espousal of Aboriginal rights during the lead-up to the bicentenary; at that point, "in the eyes of conservatives Clark moved from being an apologist for the Labor Party to a traitor ${ }^{\prime}{ }^{8}$ As well, in the early 1990 s Clark was widely credited with being the inspiration for Paul Keating's 'Big Picture' republican nationalism. In these ways, Clark became a subject of the Australian History Wars as well as a participant.

3 Cassandra Pybus, The Devil and James McAuley, Brisbane: University of Queensland Press, 1999, p. 152; Mark McKenna, An Eye for Eternity: The Life of Manning Clark, Melbourne: Miegunyah Press, 2011, pp. 387-88.

4 Frank Bongiorno, The Eighties: The Decade that Transformed Australia, Melbourne: Black Inc., 2015, p. 247.

5 Graham Freudenberg, A Figure of Speech: A Political Memoir, Brisbane: Wiley, 2005, p. 194.

6 Manning Clark, 'History will be kinder to Labor than the people', Australian, 7 January 1976, p. 7; Clark, 'The Years of Unleavened Bread: December 1949 to December 1972', Meanjin Quarterly, vol. 32, no. 3, 1973, pp. 245-50; Clark, 'Are we a Nation of Bastards?' Meanjin Quarterly, vol. 35, no. 2, 1976, pp. 215-18.

7 Manning Clark, A Discovery of Australia: The 1976 ABC Boyer Lectures and their 1988 Postscript, Sydney: ABC Enterprises for the Australian Broadcasting Commission, 1991.

8 McKenna, An Eye for Eternity, p. 620. 
Keating became prime minister in December 1991 and set about implementing his 'Big Picture'-a broad program that involved Aboriginal reconciliation, engagement with Asia and making Australia a republic. He had a vision, he was a man in a hurry and he needed no encouragement to trample over opponents. Part and parcel of republicanism, in Keating's mind, was a repudiation of the British link and associated Brit-bashing. He left his position in no doubt. In a stirring parliamentary delivery early in his tenure as prime minister, he brought up past grievances towards Britain as well as condemning the 'fogeyism of the fifties' and 'that awful cultural cringe under Menzies which held us back for nearly a generation'-the so-called 'golden age when vast numbers of Australians never got a look in'. Amid uproar in the House, he threw down the gauntlet with a rousing denunciation of the Opposition:

You can go back to the fifties to your nostalgia, your Menzies, the Caseys and the whole lot. They were not aggressively Australian, they were not aggressively proud of our culture, and we will have no bar of you or your sterile ideology.

And to think that only eight years earlier Clark considered Keating to be 'lacking in old-fashioned [?] moral passion, and indignation and anger'. ${ }^{10}$

A kindly Keating biographer has asserted:

one of the responsibilities of national leaders is to clarify a country's rhetoric and define-or redefine- the way in which a country sees itself, and few would dispute that Australia in 1992 was a country in need of some redefinition. ${ }^{11}$

Clark, had he still been alive, would certainly have thought so. But there was insufficient electoral demand for a republic or for other aspects of the Big Picture, as Keating's advisers recognised. ${ }^{12}$ It was Keating's misfortune that a recession focused people's attention on bread-and-butter issues and his support for the arts in straitened times was viewed askance. Neither

9 Hansard (House of Representatives), 27 February 1992, pp. 373-74, for quotation see p. 473; also available as a video clip at: australianpolitics.com/1992/02/27/keating-blasts-liberal-party-fogies.html.

10 Roslyn Russell (ed.), Ever, Manning: Selected Letters of Manning Clark, 1938-1991, Sydney: Allen \& Unwin, 2008, p. 443 (Clark to John Molony, 28 May 1984).

11 Michael Gordon, A Question of Leadership: Paul Keating, Political Fighter, Brisbane: University of Queensland Press, 1993, p. 196; cf. Robert Manne, 'Paul Keating' (1996 and 2002), in Manne, Left Right Left: Political Essays, 1977-2005, Melbourne: Black Inc., 2004, pp. 335-41.

12 John Edwards, Keating: The Inside Story, Ringwood: Penguin Books, 1996, pp. 526-28; Don Watson, Recollections of a Bleeding Heart: A Portrait of Paul Keating PM, Sydney: Knopf, 2002, pp. 563, 587. 
did Keating's tactics have appeal. Keating had been warned that, by making anti-British jibes the touchstone of his republican crusade would detract from his message and antagonise much of the electorate, as his abrasive style was already doing. ${ }^{13}$ But he couldn't help himself. Keating's Brit-bashing and disparagement of Menzies was a sport, for the deliberate purpose of infuriating the opposition, who obligingly rose to the baitor, to change the imagery, Don Watson likened it to a piece of cat fur being thrown to a pack of dogs. ${ }^{14}$ It would come back to haunt him. The problem was that when he tried, after 1993, to articulate a more middleof-the-road position on the republic, it was too late: he had already injected a Manning Clark faultline through the nation between 'young tree green' Labor nationalists and 'old dead tree' bootlicking Tories. ${ }^{15}$ In the event, his 'Big Picture' was ultimately unrealised and all the while the History Wars were intensifying.

The question remains: to what extent was Keating a Clark acolyte? They first met in 1985. As Keating explains:

I used to drop in on him not to draw any particular wisdom from him but simply because I liked him and enjoyed sharing the music with him. But we did share a lot of common ground. He despised the notion of the Austral Briton and its domination of the political debate, particularly after the First World Warwhere they imposed their values on society, never thinking of the Australian way and how Australia was entitled to be a society that gave expression to its own mores and values. ${ }^{16}$

13 James Curran and Stuart Ward, The Unknown Nation: Australia after Empire, Melbourne: MUP, 2010, p. 226; Stuart Ward, Australia and the British Embrace: The Demise of the Imperial Ideal, Melbourne: MUP, 2001, p. 1; Neal Blewett, A Cabinet Diary: A Personal Record of the First Keating Government, Adelaide: Wakefield Press, 1999, p. 100; Watson, Recollections of a Bleeding Heart, pp. 563-64 ('He was squandering his substance with his style').

14 James Curran, 'Ruled by Britannia', review of Robert Menzies: The Art of Politics, by Troy Bramston, Weekend Australian Review, 11-12 May 2019, p. 22.

15 James Curran, 'The "Thin Dividing Line": Prime Ministers and the Problem of Australian Nationalism, 1972-1996', Australian Journal of Politics and History, vol. 48 , no. 4, 2002, pp. 469-86, specifically p. 485, doi.org/10.1111/1467-8497.00271.

16 Kerry O’Brien, Keating, Sydney: Allen \& Unwin, 2015, for quotation see p. 520; David Day, Paul Keating: The Biography, Sydney: Fourth Estate, 2015, pp. 303-05; McKenna, An Eye for Eternity, pp. 609-11. 
Peter Ryan certainly thought that Clark had a baleful effect on Keating and that the latter's 'republican drive was largely "underpinned" by Manning Clark's writings and philosophy'. ${ }^{17}$ Ryan went on to say that 'it mattersbecause it affects things / e.g. Keating has been fed M. Clark \& comes out with $\ldots$ anti-Brit nonsense'. ${ }^{18}$ Ryan's was the prevailing view: friend and foe alike were deceived by appearances into magnifying the extent of Clark's influence over Keating. ${ }^{19}$ Peter Craven disagreed, saying that to suggest that Keating's vision came out of Clark's History is 'a shade sillier than suggesting that Harold Wilson, say, derived his vision, if he had any such thing, from E.P. Thompson's The Making of the English Working Class..$^{20}$ But his was a minority voice at the time.

Keating himself imparted the impression of a relationship that was closer than it actually was. He appropriated Clark's imagery and posited a struggle between progressive 'enlargers' like himself and the stick-inthe-mud 'straiteners' and museum pieces who infested the Opposition benches. As Don Watson recalled, this distinction did not come from Keating actually having read Clark's History:

The PM was himself responsible for the 'punishers and enlargers' rhetoric in the [1993] election campaign. On a plane back from Adelaide he was telling me how he saw the world and how his opponents seemed to see it. I simply told him he had divided people into the categories Manning Clark often used. Thereafter nothing could stop him using them. ${ }^{21}$

Keating did have a high regard for Clark. As well as delivering a eulogy in parliament when Clark died, Keating came out swinging on Clark's behalf when the Ryan controversy broke out. ${ }^{22} \mathrm{He}$ also opened the Manning

17 Ryan, notes of telephone conversation with Brian Millership, 6 March 1995, Ryan Papers, National Library of Australia (hereafter NLA), MS 9897, Series 6, Box 10, Folder 8.

18 Ryan, undated note to himself, Ryan Papers, NLA, MS 9897, Series 6, Box 10, Folder 5.

19 Hansard (Senate), 7 September 1993, pp. 1120-23 (C.R. Kemp); Geoffrey Bolton, 'Oedipus Clark for the Nineties', Editions, no. 17, August-September 1993, p. 9; Bolton, 'Don't smash the icon', Bulletin, 12 October 1993, pp. 42-43, specifically p. 43; 'Campbell not expecting to be expelled', Canberra Times, 27 November 1993, p. 6; Barry Jones, A Thinking Reed, Sydney: Allen \& Unwin, 2006, p. 302.

20 Peter Craven, 'Clark cacophony revisited', Australian, 25 May 1994, p. 29.

21 Mark McKenna, "I wonder whether I belong” Manning Clark and the Politics of Australian History, 1970-2000', Australian Historical Studies, vol. 34, no. 122 (2003), pp. 364-83, for quotation see p. 380, doi.org/10.1080/10314610308596260.

22 Hansard (House of Representatives), 28 May 1991, p. 4032; Scott Henry and Robert Garran, 'Keating lauds Clark's gift of imagination', Weekend Australian, 28-29 August 1993, p. 4; Karen Middleton, 'Manning Clark's critics bitchy: PM', Age, 28 August 1993, p. 3; 'PM backs historian', Canberra Times, 28 August 1993, p. 1. 
Clark Centre at ANU in late February 1994, where he said that he regarded Clark as 'a great Australian'. ${ }^{23}$ He hastened to add that they were by no means close friends - only that they shared a vision about Australia's future. What the press picked up on was his wish that Clark were still alive to see such changes as the republican push and the passage of the Native Title legislation, thus giving more weight to their relationship than it warranted..$^{24}$

Rather, Clark merely reinforced the anti-British, pro-Asia strain in Keating's thinking. Since at least the 1950s Clark saw that Australia's future as part of Asia was impeded by the White Australia policy, whereas the rationale for Keating's engagement with Asia came from a different direction: it was to accommodate global political and economic realignments following the collapse of the Soviet Union. ${ }^{25}$ As a cultural nationalist, Clark wanted a more 'distinctive' national culture rather than one that was derivative of and deferential to Britain and being governed by people he was pleased to describe as 'the sycophants and career men of the Menzies circus' ${ }^{26}$ Clark's anti-British strain independently dovetailed with Keating's views:

The fall of Singapore and Australia's place in Asia did not come from the History. They were reference points that Paul Keating drew from his own [Irish working class] childhood, distilled from Labor lore and conjured from his convictions. ${ }^{27}$

A specific and significant source of political inspiration, from the early 1960s, stemmed from the nationalist fervour of his mentor, Jack Lang. ${ }^{28}$ Donald Horne put it more starkly in saying:

Keating's own experience of Australian history seems to be confined to a few scraps of Labor myth he picked up out of Jack Lang's recycle bin when, as a young acolyte, he used to visit the old demagogue-although behind Lang some have divined the evil spirit of Clark. ${ }^{29}$

23 'Speech by the Prime Minister the Hon P.J. Keating, MP - Opening of the Manning Clark Centre, ANU, Canberra 22 February 1994', available at: pmtranscripts.pmc.gov.au/release/transcript-9126.

24 'Changes would please Clark: PM', Canberra Times, 23 February 1994, p. 3.

25 McKenna, An Eye for Eternity, pp. 350-54; Watson, Recollections of a Bleeding Heart, pp. 70-72, 77-78.

26 Quoted in McKenna, An Eye for Eternity, p. 383.

27 Stuart Macintyre and Anna Clark, The History Wars, 2nd edn, Melbourne: MUP, 2004, p. 63.

28 James Curran, The Power of Speech: Australian Prime Ministers Defining the National Image, 2nd edn, Melbourne: MUP, 2006, pp. 190-235.

29 Donald Horne, 'How Manning made his enemies', Weekend Australian, 31 August-1 September 1996, p. 18. 
Nevertheless, the received wisdom was that Clark was the intellectual sorcerer and Keating his apprentice. They certainly formed a mutual admiration society. When British journalists entered the fray, they wanted to throw The Paul \& Manning Show into disarray and bring down the curtain on what they regarded as an odious double act.

Despite the angst it caused, the Ryan-Clark controversy was dismissed at the time as a little local difficulty: 'The whole wretched affair was a nine-day wonder' is one description, referring to how long it lasted as a media sensation..$^{30}$ Both Ryan and the columnist Peter Craven wrote it off as parochialism of the sort that only Australia could accomplish. ${ }^{31}$ Not so. Far from being a parish pump affair that was largely confined to Melbourne and Sydney, the controversy was given a new lease of life when English journalists Bryan Appleyard and Paul Johnson, both of whom were visiting Australia at the outbreak of hostilities, triggered a commotion in the British press, thus drawing in another audience. Their attacks were as much a contribution to Australia's History Wars as they were an assault on Clark.

Writing for the Independent, an English national broadsheet, Appleyard threw the proverbial kitchen sink at Clark and Keating. The occasion was provided by Keating's upcoming audience with the Queen at Balmoral to declare his intention that Australia become a republic. Drawing much of his information from Ryan's first Quadrant article, Appleyard described Clark as a discredited 'monster' whose History was 'the Bible of the Labor Party ... in that it provided a long tale of bitter struggle against the colonial master'. ${ }^{32}$ Repeating Ryan's assertion that Clark was 'an imposition on Australian credulity', Appleyard linked Clark to the Ern Malley hoax. Both were frauds:

[Each] arose because of an excessive enthusiasm for a specifically Australian authenticity, a narrative or a voice that could be found nowhere else and would, therefore, advertise Australia's real

30 Stuart Macintyre, 'Why do the Tories hate Manning Clark?' in ('Symposium Defending Manning Clark'), Evatt Papers, vol. 1, no. 2, 1993, pp. 17-20, specifically p. 17.

31 Peter Ryan, 'A Reply to my Critics', in his Lines of Fire: Manning Clark \& Other Writings, ed. A.K. Macdougall, Binalong, NSW: Clarion Editions, 1997, pp. 214-22, specifically p. 214; see also Peter Craven, 'The Ryan Affair', in Carl Bridge (ed.), Manning Clark: Essays on his Place in History, Melbourne: MUP, 1994, pp. 165-87 (text), p. 224 (notes), specifically p. 179.

32 Bryan Appleyard, 'The dinkum Aussie? Strewth!' Independent (London), 8 September 1993, p. 21. 
presence as opposed to shadowy existence as a thinly populated offspring of white Europe. Mr Keating's political route to this authenticity is via republicanism.

Now in full stride, Appleyard taunted the republican ideal as simply the expression of an insecure and 'insanely politic nation'-a somewhat pitiful and distant outpost whose inhabitants were

as burdened with identity as any nation on earth. If it remains implicit rather than explicit, that is a problem, but it will not be solved by bloody, historical lies and certainly not by Canberra politicos who think they know what the nation 'must' become.

Keating's Brit-bashing, in other words, was being countered by a retaliatory dose of Aussie-bashing, and Appleyard does provide an indication of the offence caused by Keating's denigration of Australia's British linkssuch as 'the British bootstraps stuff' and 'the awful cultural cringe under Menzies'.

Appleyard's studied insults added little of value to the debate about republicanism or about Clark. Predictably enough, his swingeing attack affronted Clark's friends and supporters in Britain, and the Independent published some of their responses. Neither were these particularly helpful; a case in point was the reaction of historian David Fitzpatrick of Trinity College Dublin (and a family friend of the Clarks) who asserted, 'If Clark's earlier volumes received no searching reviews from "heavyweight academic historians" in his field, this was because there were none. He was the pioneer-ploughing his own furrow. ${ }^{33}$ This is a stark example of the all-too-prevalent hyperbole from Clark's defenders. It was as though other Australia historians of Clark's generation-Geoffrey Blainey, Geoffrey Bolton, Frank Crowley, Ken Inglis, John La Nauze, Allan Martin, A.G.L. Shaw and Geoffrey Serle spring to mind-never existed. It was as though Fitzpatrick's own father, the radical historian Brian Fitzpatrick (1905-1965), had written nothing of consequence on Australian history. ${ }^{34}$ Neither was it a case of Clark ploughing his lonely furrow so much as a different furrow. Clark was no different, say, to John

33 David Fitzpatrick, 'In defence of Australia and its influential historian' (letter), Independent, 10 September 1993, p. 21. Fitzpatrick (1948-2019) also made the point that 'nobody with Irish experience would credit [Appleyard's] claim that "Australia had a monopoly on political insanity"'. Fitzpatrick was Professor of History at Trinity College, Dublin.

34 See Don Watson, Brian Fitzpatrick: A Radical Life, Sydney: Hale \& Iremonger, 1978. 
La Nauze or Allan Martin, who ploughed their own lonely furrows during the lengthy research and writing of their political biographies of Alfred Deakin and Henry Parkes, respectively. ${ }^{35}$

More was to come a week later with another broadside of Keatingesque ferocity by Paul Johnson, a journalist, prolific popular historian, former speechwriter for Margaret Thatcher and 'all-round verbal pugilist'. ${ }^{36}$ Johnson also played to the gallery, dubbing Clark as Australia's 'fraudulent historian'. Writing for the Spectator, he dismissed Keating as a 'street-wise bruiser of Irish descent, who left school at 14 and has educated himself while eye-gouging his way to the top of Canberra politics'. ${ }^{37}$ His real venom, however, was directed at Clark ('the founder of the Pom-bashing industry, at least in its modern, pseudo-academic form') and his 'inflated reputation'. His strictures against Clark were all drawn from Ryan's first Quadrant article, which were accepted as gospel truth and which, in Ryan's words, he plundered 'to the point of plagiary'. ${ }^{38}$ Such was Johnson's dependence on Ryan that Axel Clark expressed doubts whether he had actually read a word of the History. ${ }^{39}$

Only once does Johnson go beyond Ryan, and that is the allegation that Clark was the kingmaker and master puppeteer of the Australian historical profession: 'His pupils found their way to top jobs in the university history departments where they wage a ferocious warfare against scholars who disputed the Clark line. ${ }^{40} \mathrm{He}$ also linked Clark and Keating with the comment that Ryan's exposé of the History and its author as being 'fraudulent' placed a big question mark over the Australian republican movement 'since it shows that the school of history on which it rests is fundamentally bogus'. It is absurd to claim that there was a Manning

35 J.A. La Nauze, Alfred Deakin: A Biography, 2 vols, Melbourne: MUP, 1965; A.W. Martin, Henry Parkes: A Biography, Melbourne: MUP, 1980.

36 Elizabeth Grice, 'Paul Johnson: "After 70 you begin to mellow", 4 June 2010, available at: www. telegraph.co.uk/lifestyle/7800902/Paul-Johnson-After-70-you-begin-to-mellow.html.

37 Paul Johnson, 'The Queen, Mr Keating and the case of the fraudulent historian', Spectator, 16 September 1993, p. 22. An abridged version appeared as 'Bloody Poms and uppity Aussies', Age, 4 October 1993, p. 14.

38 Peter Ryan, 'The Charge of the Lightweight Brigade', in his Lines of Fire, pp. 222-34, specifically p. 229.

39 Axel Clark to Jim Griffin, 6 September (should be October) 1993, Dymphna Clark Papers, NLA, MS 9873, Series 10, Box 35, Folder 2.

40 The notion of Clark being the godfather of Australian history was reasserted in 'Editorial: 'Manning Clark's blinkered view', Courier-Mail, 31 May 1997, p. 22. Austin Gough put his own spin on it, alleging that Clark was a 'prosy old icon looming over the mastersingers and apprentices of the highly politicised craft of Australia Studies'. Gough to Ryan, 6 September 1993, Ryan Papers, NLA, MS 9897, Series 6, Box 10, Folder 3. 
Clark school of Australian history whose adherents ran a closed shop. ${ }^{41}$ For one thing, Clark was unclonable. He was an inspirational teacher and was blessed with a group of very able students at the University of Melbourne in the late 1940s, who went on to distinguished careers in history and political science. They were everlastingly grateful to their former teacher but none sought to emulate his type of history or his style of writing. Neither did any of his PhD students. John Barrett, as we have seen, publicly repudiated him.

Johnson's so-called analysis was none other than 'a construct spun from fairy floss', to use one of Ryan's phrases about the History, ${ }^{42}$ but it was altogether too much for Noel McLachlan of the Melbourne University history department. McLachlan had been one of Clark's former students in the late forties and, like many of the others, he held his old teacher in high esteem-although he might have thought differently had he realised that Clark had recommended against the publication of his $\mathrm{PhD}$ thesis by Clarendon Press. ${ }^{43} \mathrm{He}$ made it his single-handed mission to refute the infamies about Clark in sections of the English press. A man of the left, although his patrician manner suggested otherwise, McLachlan's first career was in Fleet Street journalism before becoming an academic historian. He placed great store in his connections and influence and would have expected that he could orchestrate a defence of Clark in the English media. ${ }^{44}$

He went about it in a way that was never going to win the hearts and minds of the educated British public, such was his immoderate and belittling language in accusing the British of patronising Australians-while in the same breath patronising them. His first salvo was targeted at the Guardian: 'Surely the time has come to discuss the Australian-English connexion a little less emotively', and then he proceeded to disregard his own injunction:

41 See Macintyre and Clark, The History Wars, p. 62, for a rebuttal.

42 Peter Ryan, 'Manning Clark', in his Lines of Fire, pp. 179-214, specifically p. 180.

43 Peter Spicer to Clark, 14 September 1959, Manning Clark Papers, NLA, MS 7550, Series 1, Box 3, Folder 23: 'The original contribution ... does not seem of sufficient importance to warrant the great deal of labour that would eventually be involved in putting the manuscript in a publishable condition'. I have not been able to locate Clark's letter to the Clarendon Press.

44 Charles Sowerwine, 'Noel David McLachlan, 1927-2006', History Australia, vol. 4, no. 1, 2007, pp. 15.1-15.2, doi.org/10.2104/ha070015; Stuart Macintyre, email to author, 3 September 2018. McLachlan later involved himself from the sidelines in the Courier-Mail business: 'Manning's mauling raises a storm' (letter to editor), Weekend Australian, 31 August-1 September 1996, p. 16. 
I was abroad (comparing all the gilt vulgarity of Buckingham Palace and the Barnes and other U.S. collections for a study of New world nationalism) when Peter Ryan's peevish attack on our mutual teacher, sage and friend, Manning Clark, was published, and I find Bryan Appleyard's piece in the Independent and Paul Johnson's in the Spectator even more extraordinaryand disgraceful. ${ }^{45}$

McLachlan then provides a tedious catalogue of specific rebuttals and clarifications and concludes by saying that ignorant Anglocentric contempt' is still alive and well: 'Understanding your ex-colonies seems as hard for some of you as understanding your children-and the psychological hang-ups labyrinthine'. Unsurprisingly, the letter was spiked.

His numerous other emotionally charged letters to editors deploy the same intemperate language and they mostly fell by the wayside, including one to Robert Manne at Quadrant. ${ }^{46}$ As McLachlan admitted to Dymphna Clark, his efforts were bearing little fruit. ${ }^{47}$ But he did, on his second attempt, place a letter in the Spectator and he also managed to publish a rebuttal when Johnson reviewed the Cathcart abridgement of the History in the Times Literary Supplement, where he (McLachlan) concluded that 'Ryan, like Johnson, exhibits all the unctuous and peevish recklessness of the ageing, lapsed radical-both finding (posthumous) radical-baiting now the best and safest of blood sports' ${ }^{48}$ It was another of those interventions that saw the dialogue deteriorate into insults and that provoked Peter Craven into an effective rebuttal in the Australian. ${ }^{49}$ Not to be left out, Ryan got his own back by describing McLachlan as 'Dr "Maudlin" McLachlan'. 50

45 McLachlan to Peter Preston (editor of the Guardian), 30 September 1993, attached to McLachlan to Dymphna Clark, 6 October 1993, Dymphna Clark Papers, NLA, MS 9873, Series 10, Box 35, Folder 3.

46 McLachlan to Manne, 30 January 1994, copy in Dymphna Clark Papers, NLA, MS 9873, Series 10, Box 35, Folder 3.

47 McLachlan to Dymphna Clark, 1 February 1994, Dymphna Clark Papers, NLA, MS 9873, Series 10, Box 35, Folder 3.

48 McLachlan, 'Over Manning' (letter), Spectator, 15 January 1994, p. 24; Johnson, 'Smart Alecs' (rejoinder to McLachlan), Spectator, 22 January 1994, p. 22; Johnson, 'Blood on the wattle', review of Michael Cathcart, Manning Clark's History of Australia, abridgement, Times Literary Supplement, 13 May 1994, p. 25; McLachlan, 'Manning Clark's History of Australia' (letter), Times Literary Supplement, 3 June 1994, for quotation see p. 17.

49 Peter Craven, 'Clark cacophony revisited', Australian, 25 May 1994, p. 29.

50 Ryan, 'The Charge of the Lightweight Brigade', p. 230. 
The overlay of personal abuse in the wars of words between McLachlan and his English opponents clouded the issues at stake in Australia's History Wars. Yet the British reaction did show that linking republicanism with Brit-bashing only served to provoke an equally unseemly Aussie-bashing. Little was accomplished by rubbishing the other, except to show that feelings ran high on both sides. But the dispute did illustrate some of the fault lines surrounding the Australian History Wars. One was the notion, forcefully expressed by Ryan (following Véliz), that Volume 5:

portray[ed] an Australia teetering on the brink of bloody social revolution, groaning under the yoke of immoral British imperialism, sinking into a repulsive embourgeoisement, and finally in danger of vanishing beneath a dustbowl created by the rapacious squatters and their introduced allies the rabbits. ${ }^{51}$

Such a depiction was at odds with the countervailing notion, espoused by conservatives, that Australia was remarkably free of turmoil and had a history to be proud of. To suggest otherwise was to own up to a history of abject failure, and this was a charge that Johnson (as well as Ryan) pressed home. With Johnson, the implication was that only Australians could be so hopeless as to have so thoroughly fouled their own nest. At the same time, the stark us-or-them sentiments expressed by Keating precluded the possibility that one could be unequivocally Australian and yet retain a regard for British heritage- a point identified by Kenneth Minogue (1930-2013), a conservative Australian political scientist based at the London School of Economics. ${ }^{52}$ In Britain, as in Australia, allegiances in the History Wars were defined in ideological partisan terms.

Whatever else it was or was not, the exposure of the Ryan-Clark controversy in the English press demonstrated that it was more than a parochial Australian affair. It reached well beyond Australia's shores and had a two-hemisphere dimension. Appleyard and Johnson made sure of that.

51 Ryan, 'Manning Clark', pp. 199-200.

52 Kenneth Minogue, 'Whingeing on about Aussies and Poms', review of Michael Cathcart, Manning Clark's History of Australia, abridgement, Times, 28 March 1994, p. 39. 
Closer to home, the ghost of Clark continued as a bette noire of the right long after the dust had settled on the Ryan affair. On 24 August 1996 the Brisbane Courier-Mail caused a furore by (falsely) alleging that the Soviet Union had awarded Clark the Order of Lenin for knowingly serving its Australian operations or, at the very least, being an 'agent of influence'. ${ }^{53}$ The Courier-Mail's campaign backfired, precisely because it was so obviously a vindictive beat-up, but it showed the lengths that some were prepared to go in attempting to destroy Clark's credibility. The Order of Lenin allegations flared up again the following year when journalist Peter Kelly, who had instigated the stoush, resumed hostilities in the pages of the Australian. ${ }^{54}$ The war of words gained extra imputus a few weeks later with the publication of Humphrey McQueen's rebuttal of the CourierMail's allegation in his book Suspect History. ${ }^{55}$ Ryan was no passive bystander but, rather, had foreknowledge that the original Courier-Mail attack was afoot. ${ }^{56}$ Dymphna recalled that the Courier-Mail affair was

very, very difficult [for me]; very, very disturbing; very distressing. But I'd had, in a way, a sort of rehearsal three years earlier when Quadrant started this rampage against Manning by publishing that great long article by Peter Ryan, so I'd [already] been through the mill..$^{57}$

The Courier-Mail's beat-up was but a continuation of the serial denigration of Clark. Six weeks earlier, Alexander Downer (the new minister for foreign affairs) entered the lists, at least symbolically, by refusing to present a boxed set of Clark's History to Georgetown University in Washington, DC; instead, he gave a copy of an (unspecified) biography of Sir John Monash..$^{58}$ Soon after, John Howard, by then the prime minister, declared his 'less than rapturous view of the Manning Clark view of Australian

53 Courier-Mail, 24 August 1996, pp. 1, 4-5 and Courier-Mail Weekend, 24 August 1996, pp. 1-4, with considerable follow-up over the next fortnight.

54 Peter Kelly, 'Manning, Marx and the medals', Weekend Australian, 1-2 March 1997, p. 26.

55 Humphrey McQueen, Suspect History, Adelaide: Wakefield Press, 1997; see also John McLaren, 'When hysteria becomes history', Sydney Morning Herald, 31 May 1997, 'Spectrum Books' section, p. 9s; Robert Manne, 'Battle for history's high ground', Weekend Australia, 7-8 June 1997, p. 23; Stephen Holt, 'The third man', Gerard Henderson, 'Get real, Clark was soft on the Soviet Union', and Andrew Field, 'Rampant ideology must be challenged', all in Courier-Mail Weekend, 20 September 1977, p. 9.

56 McKenna, An Eye for Eternity, 691. There are two files of newspaper clippings on the subject in the Ryan Papers, NLA, MS 9897, Series 6, Box 11, Folders 10 and 11.

57 Dymphna Clark, interviewed by Heather Rusden, 13 February 1997 (starting at 23.00 minutes), NLA, ORAL TRC 3548, available at: nla.gov.au/nla.obj-217338911/listen.

58 Don Watson, 'History according to Alexander Downer' (letter), Weekend Australian, 15-16 June 1996, p. 20; David McNicoll, 'Opinion', Bulletin, 25 June 1996, p. 26. 
history'; insisting that 'the balance sheet of our history is one of heroic achievement'. ${ }^{59}$ Howard and Clark were at one on a fundamental issue in dismissing 'any suggestion of Australian subservience' to Britain, but in every other respect they diverged. ${ }^{60}$ In retirement, Howard wrote a massive and laudatory history of the Menzies era. ${ }^{61}$ Although there was little chronological overlap in their accounts, given that Volume 6 of the History went little beyond 1935, Howard is diametrically at odds with Clark's views of Menzies, as he was with Clark trying 'to generate a sense of pessimism about Australia'. ${ }^{62}$

In referring to 'the balance sheet of our history', Howard was echoing Geoffrey Blainey's 1993 Latham Lecture, which deprecated what he termed the 'black-armband' view of Australian history and its association with Clark. Blainey's exact wording was:

My friend and undergraduate teacher, Manning Clark, who was almost the official historian in 1988 , ha[s] done much to spread the gloomy view and also the compassionate view with his powerful prose and his Old Testament phrases [my emphasis]. ${ }^{63}$

The published version of the lecture in Quadrant had little impact until appropriated by Howard, who had just been elected prime minister. As Blainey recalled, the phrase 'black-armband history' then 'took off like a rocket'. ${ }^{64}$ But it was a selective appropriation because Howard concentrated on Clark's gloom and simply ignored what Blainey had said about his compassion. As the 1990s unfolded, it became increasingly evident that two visions of Australia were in conflict. Both had their prime minister-Keating and Howard—and each was identified with an historian (Blainey and Clark, respectively).

59 Quoted in Anna Clark, 'Politicians using History', Australian Journal of Politics and History, 56:1 (2010): pp. 120-31, specifically p. 120, doi.org/10.1111/j.1467-8497.2010.01545.x; Macintyre and Clark, The History Wars, p. 50.

60 Stuart Ward, 'Fellow Britons?' Meanjin Quarterly, vol. 63, no. 3, 2004, pp. 56-64, specifically p. 56.

61 John Howard, The Menzies Era: The Years that Shaped Modern Australia, Sydney: HarperCollins Publishers, 2014

62 Quoted in Craig Johnstone, 'Howard raps Clark's "negative" history', Courier-Mail, 31 August 1996, p. 1.

63 Geoffrey Blainey, 'Drawing up a Balance Sheet of Our History', Quadrant, vol. 37, nos 7-8, July-August 1993, pp. 10-15, specifically p. 11.

64 Quoted in Richard Allsop, Geoffrey Blainey: Writer, Historian, Controversialist, Melbourne: Monash University Publishing, 2019, p. 191; Macintyre and Clark, The History Wars, p. 132. 


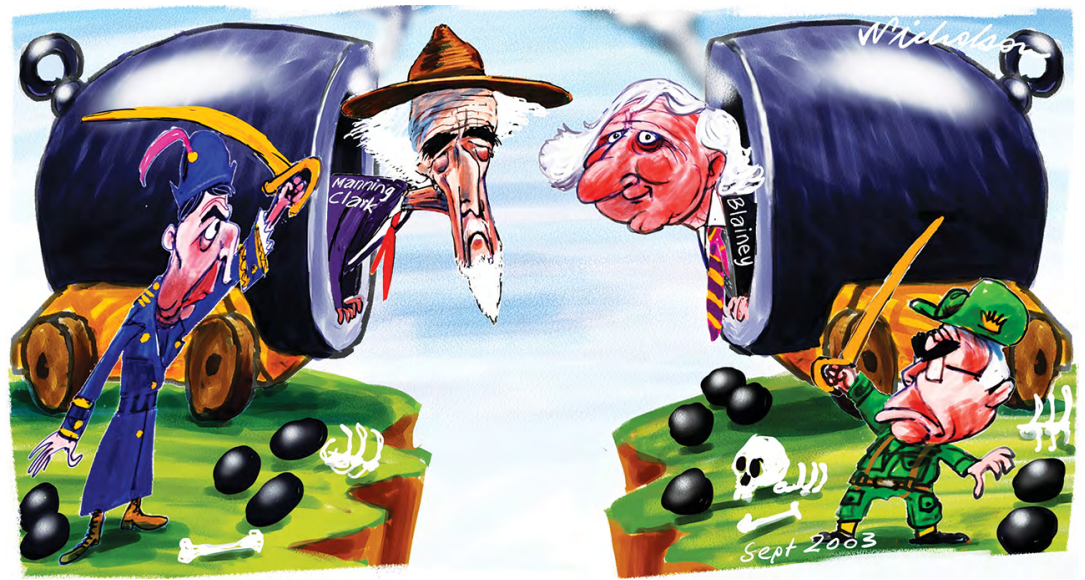

Figure 8. Paul Keating and John Howard squaring off.

Two visions of Australia were in conflict during the 1990s. Both had their prime minister, and each was identified with an historian-Manning Clark and Geoffrey Blainey, respectively.

Source. () Peter Nicholson (Rubbery Figures Pty Ltd) 2003 (nicholsoncartoons.com.au/). Reproduced with permission.

Howard's view of history largely prevailed because he was able to represent Keating's social engineering as a 'heist' —an 'attempt to rewrite history in the service of a partisan political cause ${ }^{35}$ - and he proceeded to appeal to a political constituency himself. Both Howard and Blainey embrace the notion of 'the balance sheet of history' because it gives the impression of judiciously weighing the pros and cons of a given situation, thereby occupying a moderate middle ground. But as historical geographer Alan Lester points out, the balance-sheet approach needs to be discarded because it "makes "benefits" that worked very unevenly seem universal, while it reduces "costs" to specific episodes rather than systematic features of imperial rule'. ${ }^{66}$ Notwithstanding, Howard emerged as the defender of the nation and its values and in this he was aided and abetted by 'a genuine hunger in the community for an uncomplicated and positive historical narrative that could serve as a source of national communion' ${ }^{67}$ His 'battlers', many of whom had previously voted Labor, displaced

65 Quoted in Ben Goldsmith, 'A question of inference', Brisbane Review, September 1996, pp. 3-4 (I owe this reference to Clive Moore).

66 Alan Lester, 'Time to Throw Out the Balance Sheet', Snapshots of Empire, 26 January 2016, accessible at: blogs.sussex.ac.uk/snapshotsofempire/2016/01/26/time-to-throw-out-the-balance-sheet/. I owe this reference to Nicholas Hoare.

67 Mark McKenna, 'The History Anxiety', in Alison Bashford and Stuart Macintyre (eds), The Cambridge History of Australia, Melbourne: Cambridge University Press, 2013, vol. 2, pp. 561-80, specifically p. 579. 
Keating's 'true believers' in the hustings. At the same time, Howard appropriated concepts of the left, such as mateship, to further his own agenda. ${ }^{68} \mathrm{He}$ was also the only extant Australian prime minister not to attend the apology to Indigenous Australians for the Stolen Generations in 2008. His attitude, as Ann Curthoys puts it, was that 'anything bad that happened was long ago ... has little or nothing to do with us now' ${ }^{69}$ The argument here is that contemporary white Australians had nothing to do with injustices towards Aboriginal peoples personally and therefore they bear no individual responsibility. But if those same people extol the virtues of British civilisation and see themselves as heirs to this tradition, as does Howard, then they bear a measure of inherited responsibility to address those past injustices. To put it another way, the 'three-cheers' view of Australian history is a means of evading any sort of culpability.

The irony is that during the 1950s the radical nationalist historians of left-wing persuasion had propagated a 'rosy' view of Australian history, which Clark had challenged in his ANU inaugural lecture. ${ }^{70}$ By the early 1960s, the landscape had changed and calls for a more overtly critical view of Australian history were coming from the political right. An influential collection of essays (Australian Civilization), covering a broad spectrum of Australia life and affairs, appeared in 1962. Clark was one of the contributors. The editor was Peter Coleman (1928-2019), a prominent journalist (including stints as editor of the Bulletin and Quadrant), social critic and later a Liberal Party politician, who concluded his introductory chapter by saying that 'signs of real maturity are ... clearly apparent in the growing willingness to criticize Australian life frankly and firmly, to see it clearly and wholly with all its limitations' ${ }^{71}$ By the 1980 s there had been another about-turn in political alignments over the country's past, and conservatives were now taking the rosy view and condemning the left for tarnishing the Australian achievement with its pessimism and recriminations.

68 Judith Brett, 'Relaxed and Comfortable: The Liberal Party's Australia', Quarterly Essay, no. 19, 2005, pp. 1-79, specifically pp. 35-36; Allsop, Geoffrey Blainey, p. 202.

69 Ann Curthoys, 'History in the Howard Era', talk to the Professional Historians' Association of New South Wales, 19 July 2006 (p. 7 of typescript), available at: www.phansw.org.au/wp-content/ uploads/2012/11/CurthoysHistoryintheHowardEra.pdf.

70 Manning Clark, 'Re-writing Australian History', in T.A.G. Hungerford (ed.), Australian Signpost: An Anthology, Melbourne: F.W. Cheshire, 1956, pp. 130-43.

71 Peter Coleman, 'Introduction: The New Australia', in Coleman (ed.), Australian Civilization: A Symposium, Melbourne: F.W. Cheshire, 1962, pp. 1-11, specifically p. 11; see also Allsop, Geoffrey Blainey, pp. 191-92. 
Just teach the Facts and the Dates

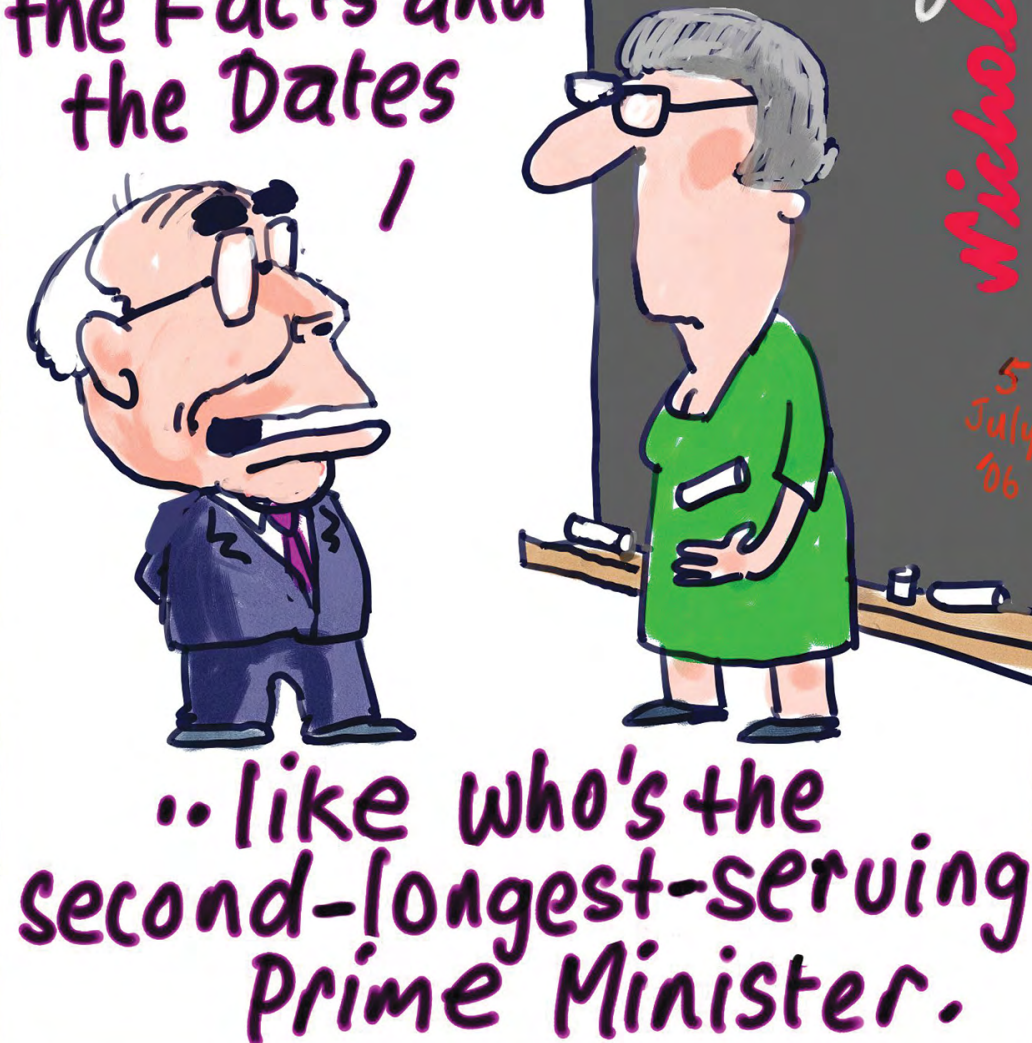

prime Minister.

Figure 9. John Howard on history, facts and dates, 5 July 2006.

with permission.

e national narrative, as well as dismal

howard continued to express his scorn at Clark being the darling of the

of black-armband history -which was to exaggerate Clark's role and 
reach. ${ }^{72}$ Howard's counter-revolution has aptly been described as the work of 'the cultural traditionalist as populist', ${ }^{73}$ which enabled him to give the impression of occupying a moderate and righteous middle ground. Keating did have a vision, if clumsily applied in places, whereas Howard weighed into the History Wars with an insular and rigid chauvinism. His counter-revolution involved a mindless and cloying patriotism in which a whitewash of the nation's past and a defence of the nation's honour were one and the same. It carried the clear implication that all decent people and responsible citizens subscribed to his complacent brand of patriotism. The rest were beyond redemption. Keating was just as intolerant in his own way, even though his Big Picture was presented as a discourse of national unity. In Don Watson's words, 'If you couldn't see the big picture, you didn't belong' ${ }^{74}$ Such is the stuff of History Wars anywhere, and not just the Australian variety; they are about politics rather than about history with each side attempting to imprint its own ideological stamp, often by whatever means.

72 The considerable literature on Howard's part in the Australian History Wars includes: Sean Brawley, "A comfortable and relaxed past": John Howard and the "Battle for History": The First Phase-February 1992 to March 1996', Electronic Journal of Australian and New Zealand History, 1997, pp. 13-25, available at: webarchive.nla.gov.au/awa/20070904044916/http://www.jcu.edu. au/aff/history/articles/brawley.htm; Andrew Bonnell and Martin Crotty, 'Australia's History under Howard, 1996-2007', Annals of the American Academy of Political and Social Science, vol. 617, no. 1, 2008, pp. 149-65, doi.org/10.1177/0002716207310818.

73 Paul Kelly, The March of Patriots: The Struggle for Modern Australia, Melbourne: MUP, 2009, pp. 328-40.

74 Watson, Recollections of a Bleeding Heart, p. 92; see also Brett, 'Relaxed and Comfortable', pp. 20-21. 
This text is taken from History Wars: The Peter Ryan-Manning Clark Controversy, by Doug Munro, published 2021 by ANU Press, The Australian National University, Canberra, Australia.

doi.org/10.22459/HW.2021.07 